ville resultere $i$ en opdragelse af moderen til at efterleve amning, ro, renlighed og regelmæssighed $\mathrm{i}$ omgangen med de nyfødte.

Som i tilfældet med sundhedsplejersken ville moderen hermed være gennemgået en dannelsesproces, der ikke blot indebar en passiv indoptagelse af en borgerpligt, som hun var blevet påtvunget af staten. Spædbørnsmødre og sundhedsplejersker er derimod blevet formet som kvinder med en bestemt selvbevidsthed og dagligdags praksis ved frivilligt at underlægge sig statens befolkningspolitiske strategi og dermed opnå anerkendelse for at opfylde kravene til en bestemt identitet. På den baggrund bliver det også forståeligt, hvorfor mange kvinders subjektivitet er snævert knyttet til velfærdsstaten og dens politiske projekt. Det er nok den mest interessante konklusion, der kan drages af Buus' værk, som i øvrigt er kendetegnet ved at være både gennemarbejdet og velskrevet. Havde analysen fulgt nærmere op på den pågxldende relation mellem velfærdspolitik og kvindelig subjektivitet og måske havde belyst den $i$ et mere aktuelt perspektiv, havde værket vundet relevans. I stedet fremstår det til en vis grad som en fortabelse i et historisk arkivmateriale, der er udstyret med et unødvendigt tungt videnskabsteoretisk apparat.

Anders Draby Sorensen

\section{Rummets og tankens strukturer}

Erwin Panofsky, Pierre Bourdieu, Gotik arkitektur - skolastik - babitus, Forlaget Klim, Arbus, 2002, 176 sider, 239 kr.

Et sted hos Thomas Aquinas hedder det: nam et sensus ratio quaedam est, "thi også sansen er en slags fornuft". Udsagnet spiller en afgørende rolle i Erwin Panofskys epokegørende Gothic Architecture and Scholasticism (1951), i hvilken der fremlæses en fundamental homologi mellem skolastikkens dialektiske tænkning og den højgotiske kirkearkitektur, et sammenfald af strukturligheder der ifølge Panofsky er så ubestrideligt, at det ikke kan have tilfældighedens karakter. Dette sammenfald består for en ydre betragtning i, at kunsthistorikerne og filosofihistorikerne inddeler periodens materiale på identiske måder. For en betragtning af mere substantiel karakter drejer ligheden sig om, at såvel de højgotiske bygmestres katedraler som de skolastiske filosoffers summae er gennemtrængt af forestillingen om, at fornuften manifesterer sig i verden. Højskolastikkens grundlæggende idé var, anderledes formuleret, at det er muligt ved tankens klarhed at forsone fornuftens kritiske blik med accepten af de religiøse sandheders åbenbarede karakter. At sansen også er en slags fornuft refererer hos Thomas til det dobbelte forhold, at den menne- 
skelige perception af sig selv udfører et ordningsarbejde $\mathrm{i}$ forhold til det perciperede, og at sanserne finder velbehag i velproportionerede, harmoniske former. Men samtidig refererer udsagnet også til et forhold der kan udstrækkes til højskolastikkens og højgotikkens periode som sådan. At sansen er en slags fornuft refererer således også til, at der er en fornuft i det sanselige, at fornuften er håndgribelig i sanselighedens medium. Det er her Panofskys analyse sætter ind. Udgangspunktet for analysen er, at de gotiske katedraler der bygges i området Île-de-France i perioden ca. 1270 til 1330 følger et udviklingsforløb der modsvarer den højskolastiske summas struktur og - ikke mindst - dens ideal om manifestatio. Idealet om at fornuften kan oplyse og sandsynliggøre trossandhederne, bliver af katedralernes bygmestre indoptaget og formidlet som konkrete arkitektoniske formprincipper og problematikker. Analysen forekommer plausibel idet Panofsky i kraft af lige dele historisk-filosofisk lærdhed og æstetisk sans for detaljen, formår at sammenbinde den overordnede tese med konkrete eksempler på hvordan problemer med udformningen af rosevinduer hhv. søjler og triforier fra katedral til katedral skred frem efter skolastikkens dialektiske skema: sic - non-respondeo dicendum. Grundlaget for antagelsen af en sammenhæng mellem skolastik og gotik er ifølge Panofsky lokaliseringen af en mental habit, en skolastisk habitus som byg- mestrene altså delte med katedralskolernes lærde, og som bestemte deres tænke- og handlemåde.

Det er ved dette begreb - habitus - at Pierre Bourdieu knytter an. I 1967 oversatte Bourdieu Gotbic Architecture and Scholasticism til fransk. Oversættelsen forsynede han med et efterskrift hvori han reflekterer over habitusbegrebets betydning for sociologiens forsøg på at beskrive samfundet. I Panofskys værk fandt Bourdieu grundlaget for et mere præcist begreb om habitus, end det der er indeholdt i det traditionelle begreb. I efterskriftet betoner Bourdieu således, at det bemærkelsesværdige ved Panofskys teori er, at habitus her løftes ud af individets og morallærens sfære, hvorved det $i$ ét greb bliver muligt at påvise og analysere homologier mellem de delområder der udgør det sociale felt. Det originale ved Bourdieus videreudvikling af habitusbegrebet er, at han formår at udnytte et upåagtet refleksionspotentiale i højskolastik og -gotik til en kritik af positivismen indenfor sociologien. At sansen også er en slags fornuft udmønter sig i Bourdieus håndtering til den epistemologiske indsigt, at isolationen af objekter og subjekter ikke giver mening for et sociologisk forsøg på at beskrive den samfundsmæssige virkelighed. Det vi ifølge Bourdieu også kan uddrage af Gotbic Architecture and Scholasticism er, at en given periodes 'virkelighed' kan siges at være bundet sammen af en habitus der kommer til udtryk i 
såvel de materielle strukturer og rumformer der omgiver individerne, som det intellektuelle og æstetiske beredskab hvormed vi opfatter og forstår disse strukturer og rumformer.

Udover at Gotbic Architecture and Scholasticism præsenteres for første gang på dansk og at vi får en god introduktion til såvel Panofsky som Bourdieu - fint skrevet af Lise Bek og Vagn Lyhne - får vi altså præsenteret en finurlig sammenhæng mellem to så tilsyneladende forskellige områder som middelalder-arkitekturteori og moderne sociologi. Læseren får med andre ord indsigt $\mathrm{i}$ spændvidden $\mathrm{i}$ traditionens elaborering af habitusbegrebet, samt indblik i selve 'the making of Bourdieus i dag så udbredte $o g$ anerkendte feltteori. For dette kan vi takke redaktøren Vagn Lyhne, der også tidligere har glimret med den velkomponerede antologi Tankebygninger (1994). Gotik-arkitektur-skolastik-habitus henvender sig både til den alment interesserede læser, og den læser der arbejder specifikt med arkitektur- og rumanalyse i et sociologisk perspektiv. Bogen fortjener de bedste anbefalinger.

\section{Hvem er Bendt Bendtsen?}

Anders Eblers Dam (red.), Forandre for

at bevare? -tanker om konservatisme, Gyldendal, Kobenhavn, 2003, 288 sider, $248 \mathrm{kr}$.

For nylig blev en række danskere spurgt om de konservative ministres partitilhørsforhold, og man kan roligt sige at genkendelsen ikke var stor. Det konservative folkeparti er simpelthen blevet klemt og glemt. Og sådan er billedet generelt i Europa. De kongeblå konservative er blevet afløst og overhalet af de lyseblå liberale.

I antologien Forandre for at bevare bliver de konservatives politiske situation tydelig. Dels spørger redaktøren, ph.d.-stipendiat Anders Ehlers Dam: "Eksisterer der i dag en diskrepans mellem de Konservative og det konservative?" (s.9-10) Som jeg vil vise nedenfor, svarer bidragene ikke herpå. Og her ligger netop de konservatives problem. En antologi om konservatismen finder ikke partiet interessant nok at beskæftige sig med, hvis man ser bort fra et par enkelte henkastede bemærkninger. Ingen tidligere eller nuværende konservative ministre eller MF'ere har bidraget og det eneste bidrag, der foregiver at have et politisk perspektiv, kommer fra den tidligere redaktør på avisen Dagen (der ikke forstod hverken at forandre eller bevare), Kresten Schultz Jørgensen, der efter en overfladisk tomgang omkring globalisering og netværkssamfund foregiver at skulle give en 'skitse 